\title{
Role of Dicer Enzyme in the Regulation of Store Operated Calcium Entry (SOCE) in CD4 ${ }^{+}$T Cells
}

\author{
Shaqiu Zhang ${ }^{\mathrm{a}, \mathrm{b}}$ Tamer al-Maghout ${ }^{\mathrm{b}}$ Yuetao Zhou ${ }^{\mathrm{b}}$ Rosi Bissinger ${ }^{\mathrm{b}}$ \\ Abeer Abousaab $^{b}$ Madhuri S. Salker ${ }^{b, c}$ Lisann Pelzl ${ }^{b}$ Bradley S. Cobb ${ }^{d}$ \\ Anchun Cheng $^{\mathrm{a}}$ Yogesh Singh $^{\mathrm{b}}$ Florian Lang ${ }^{\mathrm{b}, \mathrm{e}}$ \\ Institute of Preventive Veterinary Medicine, Sichuan Agricultural University, Wenjiang, Chengdu \\ city, China; ${ }^{b}$ Departments of Cardiology, Vascular Medicine and Physiology, Tuebingen University, \\ Institute of Women's Health, Tuebingen University, Tuebingen, Germany; 'Department of Comparative \\ Biomedical Sciences, The Royal Veterinary College, London, United Kingdom; 'Department of \\ Molecular Medicine II, Heinrich Heine University Düsseldorf, Düsseldorf, Germany
}

\section{Key Words}

$\mathrm{CD}^{+} \mathrm{T}$ cells $\cdot$ Dicer $\cdot \mathrm{SOCE}$ and miRNAs

\begin{abstract}
Background/Aims: Activation of T cell receptors (TCRs) in CD4 ${ }^{+} \mathrm{T}$ cells leads to a cascade of signalling reactions including increase of intracellular calcium $\left(\mathrm{Ca}^{2+}\right)$ levels with subsequent $\mathrm{Ca}^{2+}$ dependent stimulation of gene expression, proliferation, cell motility and cytokine release. The increase of cytosolic $\mathrm{Ca}^{2+}$ results from intracellular $\mathrm{Ca}^{2+}$ release with subsequent activation of store-operated $\mathrm{Ca}^{2+}$ entry (SOCE). Previous studies suggested miRNAs are required for the development and functions of $\mathrm{CD}^{+}{ }^{+} \mathrm{T}$ cells. An enzyme called Dicer is required during the process of manufacturing mature miRNAs from the precursor miRNAs. In this study, we explored whether loss of Dicer in $\mathrm{CD}^{+}{ }^{+} \mathrm{T}$ cells affects SOCE and thus $\mathrm{Ca}^{2+}$ dependent regulation of cellular functions. Methods: We tested the expression of Orai1 by q-RT-PCR and flow cytometry. Further, we measured SOCE by an inverted phase-contrast microscope with the Incident-light fluorescence illumination system using Fura-2. Intracellular $\mathrm{Ca}^{2+}$ was also measured by flow cytometry using $\mathrm{Ca}^{2+}$ sensitive dye Fluo-4. Results: We found that in Dicer deficient $\left(\right.$ Dicer $\left.^{\Delta / \Delta}\right)$ mice Orai1 was downregulated at mRNA and protein level in CD4 ${ }^{+} \mathrm{T}$ cells. Further, SOCE was significantly smaller in Dicer ${ }^{\Delta / \Delta} \mathrm{CD}^{+} \mathrm{T}$ cells than in $\mathrm{CD} 4^{+} \mathrm{T}$ cells isolated from wild-type (Dicer $\left.{ }^{f / f f}\right)$ mice. Conclusion: Our data suggest that miRNAs are required for adequate $\mathrm{Ca}^{2+}$ entry into $\mathrm{CD} 4{ }^{+} \mathrm{T}$ cells and thus triggering of $\mathrm{Ca}^{2+}$ sensitive immune functions.
\end{abstract}

\section{Introduction}

After antigen-specific T cell activation, an increase of intracellular $\mathrm{Ca}^{2+}$ levels is required to induce gene expression, proliferation, cell motility and cytokine expression [1-3]. In resting $\mathrm{T}$ cells, $\mathrm{Ca}^{2+}$ is stored in the endoplasmic reticulum (ER) where it is sensed by stromal

Yogesh Singh

Florian Lang 
cell-interaction molecules (STIM) 1 and 2. In T cells, signalling through the T cell receptor results in the production of inositol trisphosphate $\left(\mathrm{IP}_{3}\right)$, which binds to $\mathrm{IP}_{3}$ receptors on the $\mathrm{ER}$ and results in the release of $\mathrm{Ca}^{2+}$ into the cytosol. The depletion of $\mathrm{ER} \mathrm{Ca}^{2+}$ results in $\mathrm{Ca}^{2+}$ influx across the plasma membrane by store-operated $\mathrm{Ca}^{2+}$ entry (SOCE) [2, 4-7]. It entails activation of the calcium release-activated calcium (CRAC) channel protein 1 (encoded by Orai1 gene) through the binding of the ER $\mathrm{Ca}^{2+}$ sensors STIM1 and 2. $\mathrm{Ca}^{2+}$ influx through Orai1 in $\mathrm{T}$ cells depends on a negative membrane potential that provides the electrical driving force for $\mathrm{Ca}^{2+}$ entry $[2,6,8,9]$. The importance of ion channel function in $\mathrm{T}$ cells comes largely from genetic studies in mice through knockout or siRNA mediated knock down of specific ion channel genes $[2,6]$. Mice genetically defective for STIM1/2 or Orai1 have impaired T cell development, which is not surprising considering the important role these molecules play in $\mathrm{Ca}^{2+}$ signalling [5, 8-10]. The regulation of the function of Orai1 channels could affect the signalling in $\mathrm{T}$ cells and play an important role in $\mathrm{CD} 4^{+} \mathrm{T}$ cells development and function [13].

MicroRNAs (miRNAs) are transcribed in the genome as a part of Pol II transcribed messages and function as post-transcriptional gene regulators [11]. Biogenesis of miRNAs involves the RNase Dicer $[11,12]$. In the cell nucleus, primary miRNAs are transcribed and processed into precursor miRNAs by the enzyme complex containing the RNase Drosha. These precursor miRNAs then move out from the nucleus to cytoplasm by experotin-5, where these miRNAs are processed into mature miRNAs by Dicer. Thus in the absence of Dicer, miRNAs are not produced. Generally, miRNAs bind to the 3' untranslated region (3'UTR) of mRNAs and inhibit translation and induce message degradation [13-21]. Bioinformatics studies have predicted that almost one third of the genome is targeted by miRNAs [13, 21]. Therefore, miRNAs play decisive roles in the regulation of gene expression. Dicer is involved in the regulation of diverse biological processes including development as well as organogenesis and Dicer contributes to the development of several pathologies including cancer, infection susceptibility as well as autoimmunity [22].

$\mathrm{T}$ cell specific deletion of Dicer results in impaired $\mathrm{T}$ cell development and severely reduced numbers of regulatory T cells $[23,24]$. Dicer deficient mice develop inflammatory bowel disease by age of 6 months $[23,25,26]$, which is a similar phenotype as seen in Orai1 and STIM1/2 deficient mice $[2,8,27]$. Dicer impacts on the development of autoimmunity by controlling the immune functions of regulatory $\mathrm{T}$ cells and conventional $\mathrm{T}$ cells. Therefore, we explored whether Dicer may influence $\mathrm{Ca}^{2+}$ signalling in $\mathrm{CD}^{+}{ }^{+} \mathrm{T}$ cells.

In this study we found that Dicer deficient $\left(\right.$ Dicer $\left.^{\Delta / \Delta}\right) \mathrm{CD} 4^{+} \mathrm{T}$ cells have reduced expression of Orai1 at mRNA and protein levels. Further studies suggested that Dicer deficient CD4 ${ }^{+}$ T cells have less $\mathrm{Ca}^{2+}$ influx after activation with anti-CD3 and anti-CD28 compared with control (Dicerf/ff) $\mathrm{CD}^{+} \mathrm{T}$ cells. Thus, our data suggest that miRNAs are required for proper influx of $\mathrm{Ca}^{2+}$ after activation of $\mathrm{T}$ cells.

\section{Material and Methods}

Mice

Dicer $^{f / f l}$ mice (mixed C57BL/6/129 background) were bred with CD4 ${ }^{\text {Cre }}$ mice to generate CD4 specific Dicer $^{\Delta / \Delta}$ mice described earlier $[23,24]$ and kept in specific pathogen free conditions. Mice used for the experiments were in between 8-16 weeks of age. All the experiments were performed according to the EU Animals Scientific Procedures Act and the German law for the welfare of animals. All the procedures for the experiments were approved by the authorities of the state of Baden-Württemberg.

$C D 4^{+} T$ cell isolation and culture

$\mathrm{CD}^{+}$naïve T cells were isolated from Dicer ${ }^{f / f l}$ and Dicer ${ }^{\Delta / \Delta}$ mice using the MagniSort ${ }^{\circledR}$ Mouse naïve $\mathrm{T}$ cell Enrichment kit as described by the manufacturer (eBioscience, Frankfurt, Germany). Purified T cells were cultured in plate-bound anti-CD3: and anti-CD28 (1:2 dilution; $1 \mu \mathrm{g} / \mathrm{ml}$ anti-CD3 and $2 \mu \mathrm{g} / \mathrm{ml}$ antiCD28) for 2-3 days and then subjected to the measurement of intracellular $\mathrm{Ca}^{2+}$ by flow cytometry (Fluo-4) and fluorescence microscopy (Fura-2/AM). 


\section{Cellular Physiology Cell Physiol Biochem 2016;39:1360-1368 \begin{tabular}{l|l|l} 
and Biochemistry $\begin{array}{l}\text { DOI: 10.1159/000447840 } \\
\text { Published online: September 08, } 2016\end{array}$ & $\begin{array}{l}\text { (c) } 2016 \text { The Author(s). Published by S. Karger AG, Basel } \\
\text { www.karger.com/cpb }\end{array}$
\end{tabular} \\ Zhang et al.: Dicer Controls the Ca ${ }^{2+}$ Entry in T Cells}

Calcium measurements

Fluorescence measurements were performed using an inverted phase-contrast microscope with the Incident-light fluorescence illumination system (Axiovert 100, Zeiss, Germany). Cells were excited alternatively at $\lambda=340$ or $380 \mathrm{~nm}$ and the light deflected by a dichroic mirror into either the objective (Fluar 40×/1.30 oil, Zeiss, Germany) or a camera (Proxitronic, Germany). Emitted fluorescence intensity was recorded at $\lambda=505 \mathrm{~nm}$ and data were acquired by using specialized computer software (Metafluor, Universal Imaging, USA) [28].

Activated cells (anti-CD3/anti-CD28) for 3 days from both mice strains were loaded with Fura-2-AM ( $2 \mu \mathrm{M}$, Molecular Probes, Germany) for $30 \mathrm{~min}$ at $37^{\circ} \mathrm{C}$ in a $\mathrm{CO}_{2}$ incubator. To measure SOCE, changes in intracellular $\mathrm{Ca}^{2+}\left[\mathrm{Ca}^{2+}\right]$ i were monitored on depletion of the intracellular $\mathrm{Ca}^{2+}$ stores. In brief, $\left[\mathrm{Ca}^{2+}\right] \mathrm{i}$ was measured using $\mathrm{Ca}^{2+}$ containing standard HEPES buffer [125mM/L NaCl, $5 \mathrm{mM} \mathrm{KCl}, 1.2 \mathrm{mM} \mathrm{MgSO}_{4}{ }^{*} 7 \mathrm{H}_{2} \mathrm{O}$, $32.2 \mathrm{mM}$ HEPES, $2 \mathrm{mM} \mathrm{Na}_{2} \mathrm{HPO}_{4}{ }^{*} 2 \mathrm{H}_{2} \mathrm{O}, 5 \mathrm{mM}$ Glucose, $\left.1 \mathrm{mM} \mathrm{CaCl}{ }_{2}{ }^{2} \mathrm{H}_{2} \mathrm{O} ; \mathrm{pH}=7.4\right]$ for 2 minutes and then changed to $\mathrm{Ca}^{2+}$ free HEPES buffer [125mM NaCl, $5 \mathrm{mM} \mathrm{KCl}, 1.2 \mathrm{mM} \mathrm{MgSO}_{4}{ }^{*} 7 \mathrm{H}_{2} 0,32.2 \mathrm{mM} \mathrm{HEPES}, 2 \mathrm{mM}$ $\mathrm{Na}_{2} \mathrm{HPO}_{4}{ }^{*} 2 \mathrm{H}_{2} \mathrm{O}, 5 \mathrm{mM}$ Glucose, $0.5 \mathrm{mM}$ EGTA; $\mathrm{pH}=7.4$ ] for 3 minutes. In the absence of $\mathrm{Ca}^{2+}$, the intracellular $\mathrm{Ca}^{2+}$ stores were depleted by inhibition of the vesicular $\mathrm{Ca}^{2+}$ pump by thapsigargin ( $1 \mu \mathrm{M}$, Sigma, Germany) and $\left[\mathrm{Ca}^{2+}\right] \mathrm{i}$ activity was measured for another 5 minutes. Furthermore, $\mathrm{Ca}^{2+}$ containing HEPES buffer was added for 5 minutes, which allowed assessing SOCE.

\section{$q-R T-P C R$}

Total mRNA was isolated from Dicer $^{f / f l}$ and Dicer $^{\Delta / \Delta}$ mice using the mRNAeasy isolation kit (QIAGEN, Germany) as described by the manufacturer. $1 \mu \mathrm{g}$ mRNA was converted into cDNA using the cDNA synthesis kit (Invitrogen, Germany). Briefly, in $10 \mu \mathrm{l}$ reactions, $10 \mathrm{ng}$ cDNA, 2X SYBR green mastermix (KAPA SYBR ${ }^{\circledR}$ FAST q-PCR kit Master Mix (2x) Bio-Rad iCycler ${ }^{\text {rm; }}$ Peqlab, Erlangen, Germany) and 250 nM primers were used for q-RT-PCR reactions. q-RT-PCR run and data analysis was performed as described previously [29]. Universal cycling conditions were used $\left(95^{\circ} \mathrm{C}\right.$ for 10 minutes, $95^{\circ} \mathrm{C}$ for 15 seconds and $60^{\circ} \mathrm{C}$ for 1 minute for 40 cycles followed by melting curve analysis) for q-RT-PCR [30]. The following primers were used:

Orai1-F 5'- CCTGGCGCAAGCTCTACTTA-3'

Orai1-R 5'- CATCGCTACCATGGCGAAGC-3',

GAPDH-F 5'-TCTGACCACAGTGAGGAATGTCCAC-3'

GAPDH-R 5'-TTGATGGCAACAATCTCCAC-3'

Fluo-4 Calcium measurement by flow cytometry

Activated CD4 ${ }^{+} \mathrm{T}$ cells from Dicer ${ }^{f / f l}$ and Dicer $^{\Delta / \Delta}$ mice were washed once with PBS and then incubated in Ringer solution with calcium containing Fluo4 and Fluo3 (Invitrogen, Germany) for 30 minutes in a $37^{\circ} \mathrm{C}$ incubator as described earlier [31]. After incubation, cells were washed 3 times with Ringer solution. $200 \mu \mathrm{l}$ of Ringer solution was added, and intracellular calcium levels were measured by flow cytometry analysing 20,000 cells. Data were analysed by FlowJo (Treestar, USA)

Statistics

Data are provided as means \pm SEM. $n$ represents the number of independent experiments. Data were tested for statistical significance using unpaired Student's t-test. Data were analysed by Excel 2010 or GraphPad Prism Software, USA. A p value of $\leq 0.05$ was considered statistically significant.

\section{Results}

Orai1 expression by q-RT-PCR and flow cytometry

Previous studies suggested that various ion channels such as $\mathrm{Ca}^{2+}$ release activated $\mathrm{Ca}^{2+}$ (CRAC) channels, $\mathrm{K}^{+}$channels, TRPM4 channels, TRPM7 channels and chloride channels contribute to the pathophysiology of asthma, allergy and inflammatory bowel disease [2, $6,10]$. According to published microarray data from Dicer ${ }^{\Delta / \Delta}$ mice potassium channel $\mathrm{K}^{+}$two pore domain channel subfamily K (KCNK) 1, KCNK6 and $\mathrm{Mg}^{2+}$ permeable channel (TRPM7)

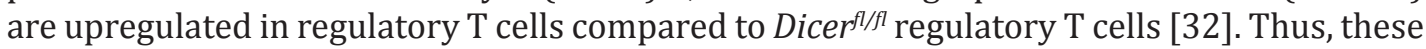
data suggested that ion channels could be dysregulated in miRNAs deficient immune T cells.

Given the important role of both $\mathrm{Ca}^{2+}$ signalling and miRNAs in key physiological processes, the role of miRNAs in the regulation of calcium channels in $\mathrm{T}$ cell differentiation KARGER 
and effective function was addressed. Channels accomplishing $\mathrm{Ca}^{2+}$ entry into lymphocytes include CRAC channels composed of the pore-forming units Orai1, 2 and 3 and their regulators STIM1 and 2, which can be activated by emptying of the intracellular $\mathrm{Ca}^{2+}$ stores [2,33]. SOCE following activation of $\mathrm{T}$ cells is mediated by the Orai1 channel protein [2]. Therefore, we measured Orai1 expression at mRNA transcript and protein levels. We observed significantly lower mRNA expression in Dicer ${ }^{\Delta / \Delta} \mathrm{CD} 4^{+} \mathrm{T}$ cells than in Dicer ${ }^{f / f l} \mathrm{CD} 4^{+} \mathrm{T}$ cells (Fig. 1A). Similarly, measurement of Orai1 expression by flow cytometry revealed that Orai1 protein abundance was significantly lower in Dicer ${ }^{\Delta / \Delta} \mathrm{CD}^{+} \mathrm{T}$ cells than in Dicer ${ }^{f / f l} \mathrm{CD} 4^{+} \mathrm{T}$ cells (Fig. 1B).

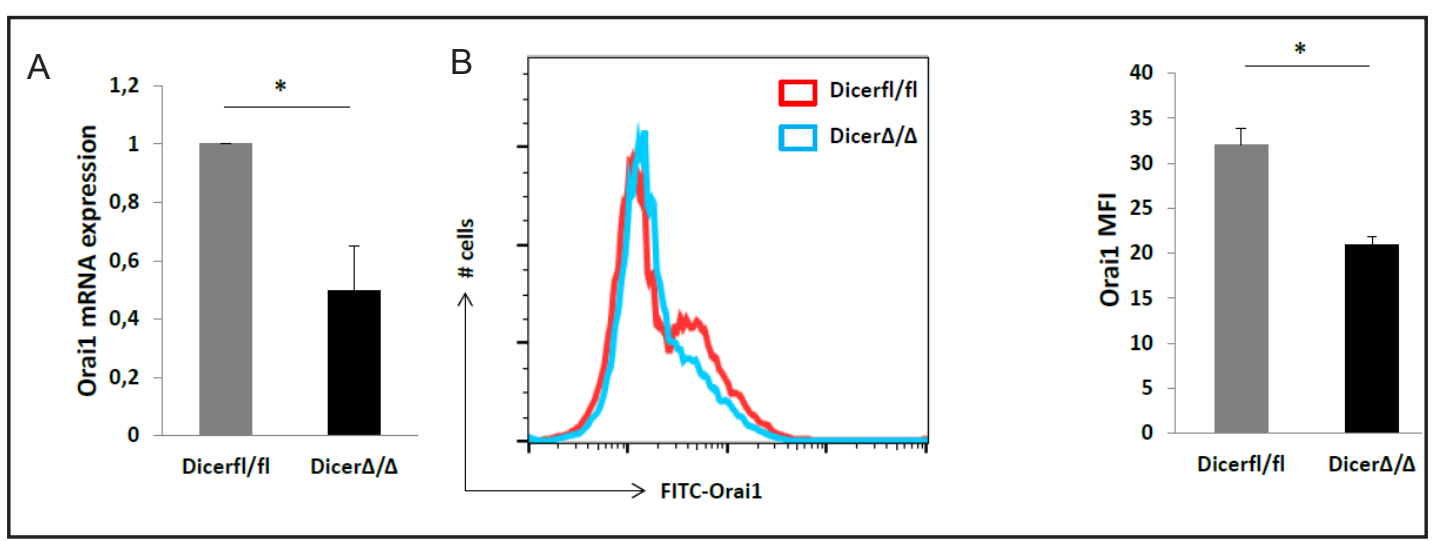

Fig. 1. Dicer ${ }^{\Delta / \Delta}$ mice express reduced Orai1 at transcript and protein levels in CD $4^{+} \mathrm{T}$ cells. A. mRNA was isolated from Dicer ${ }^{f / f l}$ and $\operatorname{Dicer}^{\Delta / \Delta} \mathrm{CD}^{+} \mathrm{T}$ cells and equal amount of mRNA was converted into cDNA. q-RT-PCR was performed for quantification of Orai1 transcript levels. B. Protein expression of Orai1 in Dicer $^{f l / f l}$ and Dicer ${ }^{\Delta / \Delta}$ CD $4^{+}$T cells by flow cytometry. Left hand side shows the representative FACS histogram of Orai1 expression and right hand side shows arithmetic means \pm SEM of $n=3$ independent experiments. * indicates statistical significance difference $(\mathrm{p}<0.05)$.

Fig. 2. Dicer $^{\Delta / \Delta}$ mice have decreased calcium influx (SOCE) in ex vivo isolated $\mathrm{CD}^{+}$ $\mathrm{T}$ cells . $\mathrm{CD}^{+} \mathrm{T}$ cells were isolated from Dicer $^{f l / f l}$ and Dicer ${ }^{\Delta / \Delta}$ mice spleen and lymph nodes and $\mathrm{Ca}^{2+}$ entry into $\mathrm{CD} 4{ }^{+} \mathrm{T}$ cells measured using Fura-2 fluorescence under an inverted phase-contrast microscope with the incident-light fluorescence illumination system. A. The average of 100-120 cells was used for measuring the $\mathrm{Ca}^{2+}$ entry. Representative tracings showing the $340 / 380$ nm fluorescence ratio in Fura-2/AM loaded $\mathrm{T}$ cells from Dicer $^{\Delta / \Delta}$ and Dicer ${ }^{f l / f l}$ mice upon removal of extracellular $\mathrm{Ca}^{2+}$ followed by exposure to thapsigargin $(1 \mu \mathrm{M})$ and $\mathrm{Ca}^{2+}$ readmission. B. Arithmetic means \pm SEM of the slope (left) and peak (right) of the fluorescence ratio change between $\operatorname{Dicer}^{\Delta / \Delta}$ and Dicer $^{f l / f l} \mathrm{CD}^{+} \mathrm{T}$ cells $(\mathrm{n}=3$; independent experiments). * indicates statistical significance difference $(\mathrm{p}<0.05)$.

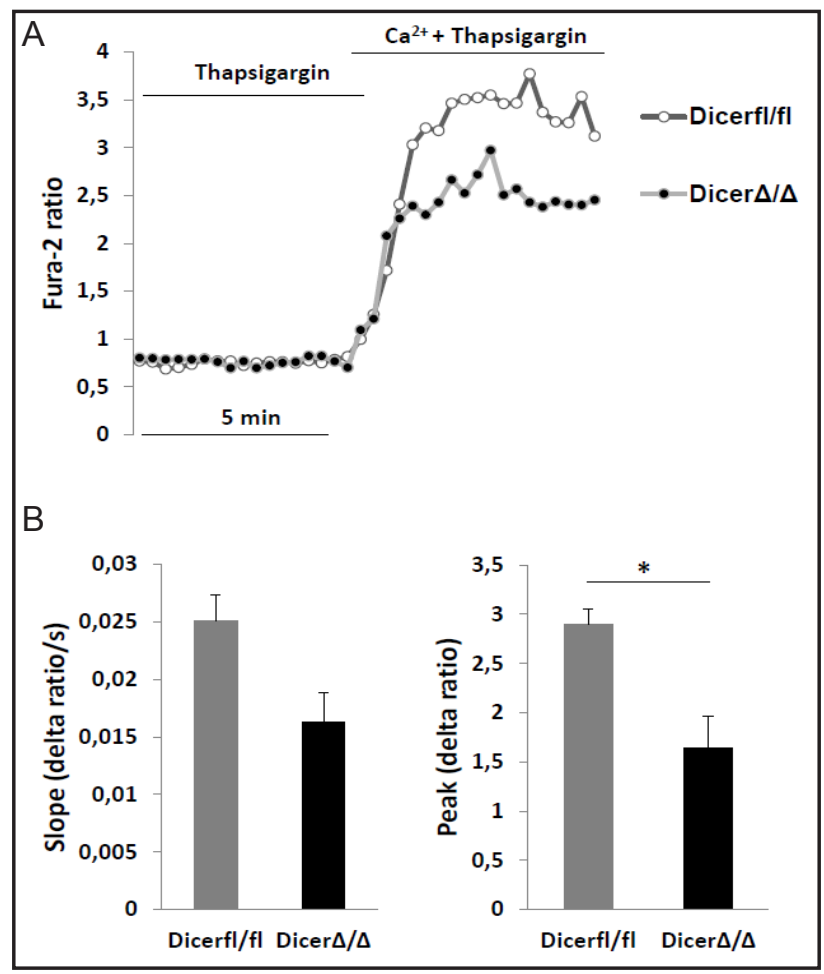


Fig. 3. SOCE is decreased in activated $\mathrm{CD}^{+} \mathrm{T}$ cells of Dicer ${ }^{\Delta / \Delta}$ mice. CD4 ${ }^{+} \mathrm{T}$ cells were isolated from Dicer ${ }^{f / f l}$ and Dicer $^{\Delta / \Delta}$ mice spleen and lymph nodes and activated in the presence of anti-CD3 and anti-CD28 (plate bound) and $\mathrm{Ca}^{2+}$ entry into $\mathrm{CD} 4{ }^{+} \mathrm{T}$ cells measured using Fura-2 fluorescence. A. Representative tracings showing the $340 / 380 \mathrm{~nm}$ fluorescence ratio in Fura-2/AM loaded activated $\mathrm{CD}^{+}{ }^{+} \mathrm{T}$ cells from Dicer ${ }^{\Delta / \Delta}$ and Dicer ${ }^{f / f l}$ mice upon removal of extracellular $\mathrm{Ca}^{2+}$ followed by exposure to thapsigargin $(1 \mu \mathrm{M})$ and $\mathrm{Ca}^{2+}$ readmission. B. Arithmetic means \pm SEM of the slope (left) and peak (right) of the fluorescence ratio change between Dicer $^{\Delta / \Delta}$ and Dicer $^{f / f f} \mathrm{CD}^{+} \mathrm{T}$ cells $(\mathrm{n}=3$; independent experiments). * indicates statistical significance difference $(\mathrm{p}<0.05)$.

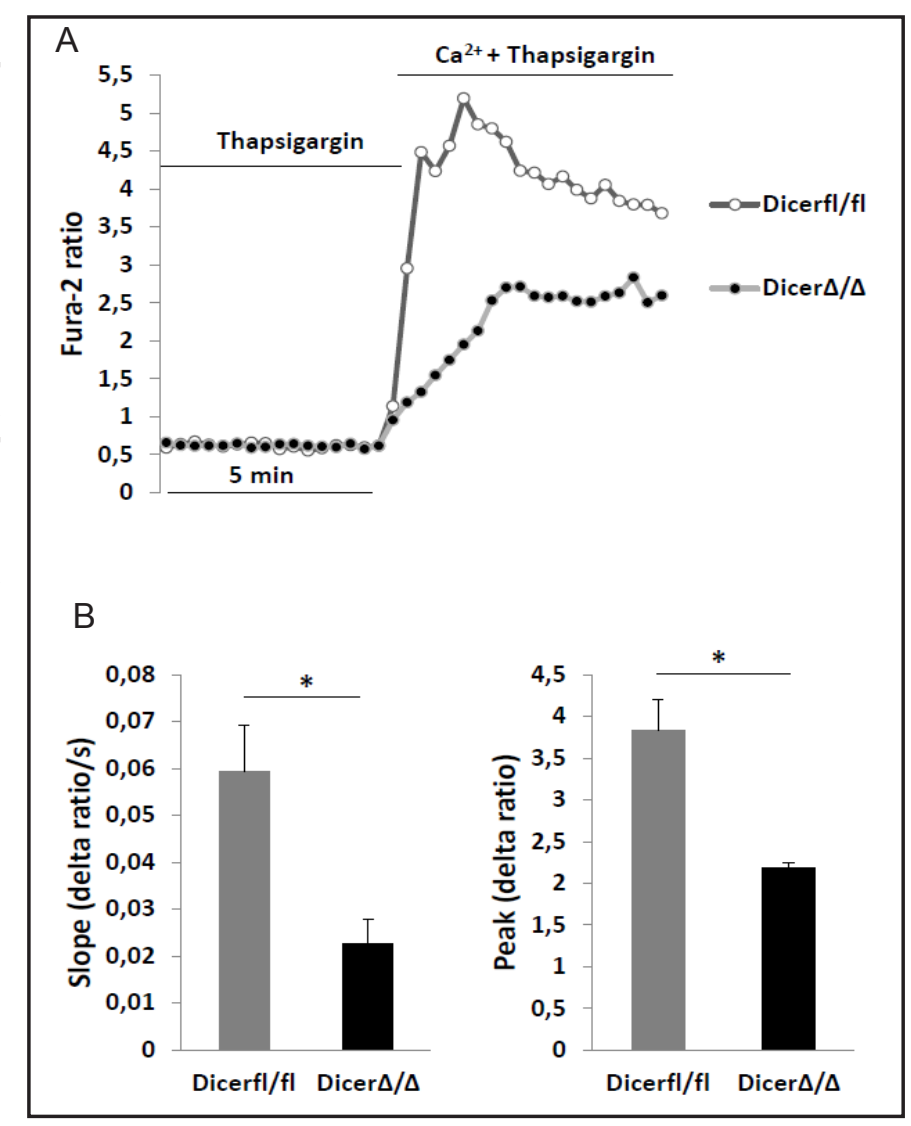

$\mathrm{Ca}^{2+}$ entry in ex vivo isolated Dicerf//fl and Dicer ${ }^{\Delta / \Delta} \mathrm{CD} 4^{+} \mathrm{T}$ cells

We explored whether SOCE into ex vivo $\mathrm{CD}^{+} \mathrm{T}$ cells is modified by Dicer deficiency $[3,34]$. Thus, we measured the intracellular $\mathrm{Ca}^{2+}$ activity $\left(\left[\mathrm{Ca}^{2+}\right] \mathrm{i}\right)$ and SOCE from Dicer $^{f / f l}$ and Dicer ${ }^{\Delta / \Delta} \mathrm{CD}^{+} \mathrm{T}$ cells using the Fura-2 AM dye. Ex vivo isolated CD4+ $\mathrm{T}$ cells from both Dicer $^{f / f l}$ and Dicer ${ }^{\Delta / \Delta}$ mice were loaded with Fura-2 for 30 minutes in standard HEPES buffer containing $\mathrm{Ca}^{2+}$ and washed once with standard HEPES buffer containing $\mathrm{Ca}^{2+}$ and then with $\mathrm{Ca}^{2+}$ free HEPES buffer. $\mathrm{Ca}^{2+}$ stores were then depleted by addition of sarco-/ endoplasmic reticulum $\mathrm{Ca}^{2+}$ ATPase (SERCA) inhibitor thapsigargin $(1 \mu \mathrm{M})$ in the nominal absence of extracellular $\mathrm{Ca}^{2+}$. The intracellular $\mathrm{Ca}^{2+}\left(\left[\mathrm{Ca}^{2+}\right] \mathrm{i}\right)$ manoeuver was similar in between Dicer $^{f / f l}$ and Dicer ${ }^{\Delta / \Delta}$ CD $4^{+}$T cells (Fig. 2A, B). Addition of extracellular $\mathrm{Ca}^{2+}(1 \mu \mathrm{M})$ in the continued presence of thapsigargin triggered SOCE. Peak of SOCE was significantly lower whereas slope of SOCE was not significantly different between Dicer $^{\Delta / \Delta}$ and Dicer $r^{f / f l}$ CD4 ${ }^{+}$T cells (Fig. 2A, B).

\section{$\mathrm{Ca}^{2+}$ entry in activated Dicer ${ }^{f / f l}$ and Dicer ${ }^{\Delta / \Delta} \mathrm{CD}^{+} \mathrm{T}$ cells}

The increase of $\left[\mathrm{Ca}^{2+}\right]$ i plays a decisive role during the initial phase of $\mathrm{T}$ cell activation, particularly for the production of cytokines, cell proliferation and cell death [2, 28, 34-37]. Therefore, we also measured the SOCE from activated CD4 ${ }^{+} \mathrm{T}$ cells. CD4 $4^{+} \mathrm{T}$ cells from both Dicer $^{f / f l}$ and Dicer $^{\Delta / \Delta}$ mice were activated for 2 days in the presence of plate-bound anti-CD3 and anti-CD28, after which $\mathrm{Ca}^{2+}$ entry was measured. Cells were loaded with Fura-2 for 30 minutes in standard HEPES buffer and washed once with standard HEPES buffer and further with $\mathrm{Ca}^{2+}$ free HEPES buffer as described in Fig.2. First, depletion of $\mathrm{Ca}^{2+}$ stores by the SERCA inhibitor thapsigargin $(1 \mu \mathrm{M})$ in the nominal absence of extracellular $\mathrm{Ca}^{2+}$ was performed. Then, $\left[\mathrm{Ca}^{2+}\right]$ i measurements were performed prior to and following addition of extracellular $\mathrm{Ca}^{2+}(1 \mu \mathrm{M})$ in the continued presence of thapsigargin resulting in SOCE. Slope and peak of SOCE were significantly lower in Dicer ${ }^{\Delta / \Delta}$ than in Dicer ${ }^{f / / f} \mathrm{CD} 4^{+} \mathrm{T}$ cells (Fig. 3A, B). In addition to this, when we compared the $\mathrm{Ca}^{2+}$ entry in between unactivated and activated $\mathrm{T}$ cells from 


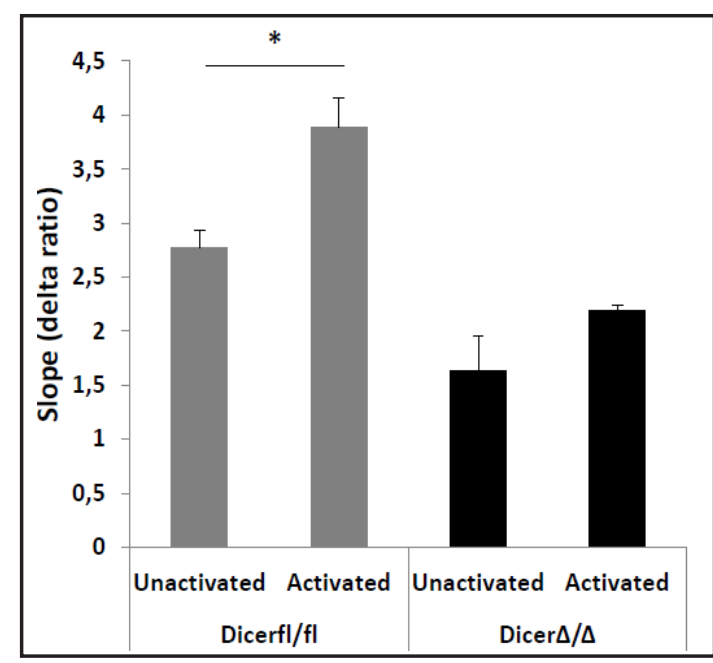

Fig. 4. Intracellular $\mathrm{Ca}^{2+}$ is increased after activation of $\mathrm{T}$ cells in $\mathrm{CD}^{+} \mathrm{T}$ cells of $\mathrm{Dicer}^{\Delta / \Delta}$ mice. Measurement of intracellular $\mathrm{Ca}^{2+}$ measurement by Fluo-2/AM dye fluorescence in unactivated and activated Dicer ${ }^{\Delta / \Delta}$ and Dicer ${ }^{f l / f l} \mathrm{CD} 4^{+} \mathrm{T}$ cells. Activated Dicer ${ }^{f l / f l} \mathrm{CD} 4{ }^{+} \mathrm{T}$ cells have significantly higher levels of SOCE compared with unactivated cells, whereas no difference was observed in Dicer ${ }^{\Delta / \Delta} \mathrm{T}$ cells. * indicates statistical significance difference $(p<0.05)$.

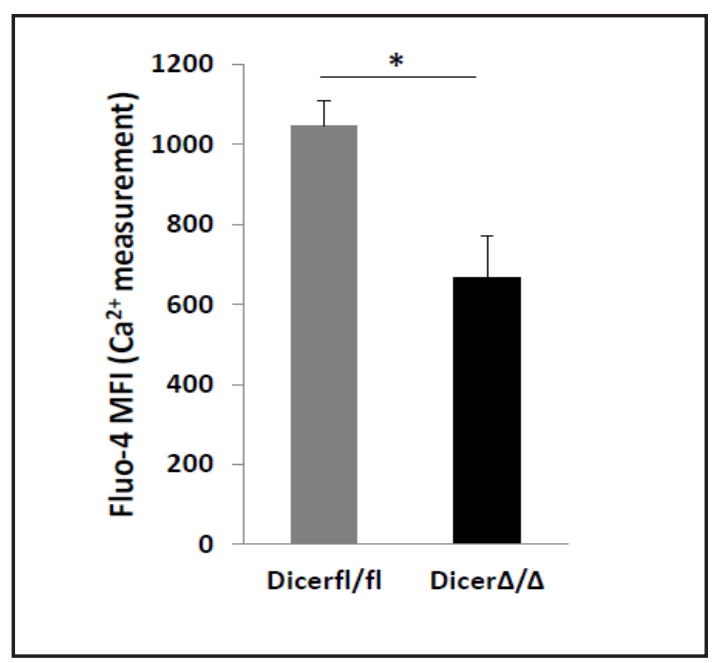

Fig. 5. Intracellular $\mathrm{Ca}^{2+}$ is decreased in anti-CD3 and anti-CD28 activated CD4 ${ }^{+} \mathrm{T}$ cells of Dicer ${ }^{\Delta / \Delta}$ mice. Measurement of intracellular $\mathrm{Ca}^{2+}$ by Fluo-4/AM dye fluorescence in activated Dicer ${ }^{\Delta / \Delta}$ and Dicer $^{f / f l} \mathrm{~T}$ cells. Dicer $^{\Delta / \Delta} \mathrm{T}$ cells have significantly less intracellular $\mathrm{Ca}^{2+}$ in comparison with Dicer ${ }^{f / f l} \mathrm{~T}$ cells. * indicates statistical significance difference $(\mathrm{p}<0.05)$.

Dicer $^{\Delta / \Delta}$ and Dicer $^{f / / f l} \mathrm{CD} 4^{+} \mathrm{T}$ cells. We found that Dicer $^{f / / f l} \mathrm{CD} 4^{+} \mathrm{T}$ cells significantly upregulated the SOCE in activated $\mathrm{T}$ cells compared with unactivated $\mathrm{T}$ cells whereas no significant difference was observed in Dicer ${ }^{\Delta / \Delta}$ CD $^{+}$T cells (Fig. 4)

$\mathrm{Ca}^{2+}$ measurement by Fluo- 4 in activated Dicer ${ }^{f / f l}$ and Dicer ${ }^{\Delta / \Delta} C D 4^{+} T$ cells

To test the effect of Dicer deletion on $\mathrm{Ca}^{2+}$ signalling by a second, independent method, we employed flow cytometry and measured $\left[\mathrm{Ca}^{2+}\right]$ i by Fluo- 4 dye. Similar to the experiments with fluorescence microscopy, Dicer ${ }^{\Delta / \Delta} \mathrm{CD}^{+} \mathrm{T}$ cells had significantly lower $\left[\mathrm{Ca}^{2+}\right]$ i than Dicer $\mathrm{f}^{\mathrm{f} / f \mathrm{f}}$ CD $4^{+} \mathrm{T}$ cells (Fig. 5).

\section{Discussion}

The present study revealed a role of miRNAs in $\mathrm{Ca}^{2+}$ homeostasis as a positive regulator of SOCE into T cells. SOCE was lower in the Dicer ${ }^{\Delta / \Delta} \mathrm{CD}^{+} \mathrm{T}$ cells compared with Dicer $^{f / / f} \mathrm{CD} 4^{+}$ $\mathrm{T}$ cells. Orai1 expression was lower in Dicer ${ }^{\Delta / \Delta} \mathrm{CD} 4^{+} \mathrm{T}$ cells compared with Dicerf/fl $\mathrm{CD} 4^{+} \mathrm{T}$ cells. Therefore, we speculate that miRNAs are required to suppress the expression of a repressor of Orai1.

Dicer is essential for maturation of miRNAs and is involved in the pathophysiology of various diseases such as cancer, infection and autoimmunity $[23,24]$. In this study, we found that activation of $\mathrm{T}$ cells with anti-CD3 and anti-CD28 leads to enhanced $\mathrm{Ca}^{2+}$ entry. This was significantly reduced in $\operatorname{Dicer}^{\Delta / \Delta} \mathrm{CD} 4^{+} \mathrm{T}$ cells even though most miRNAs show decreased expression in activated $\mathrm{T}$ cells due to the degradation of Argonaute proteins, which are the key component of the effector complex that binds the miRNA and mediate the effects on gene regulation $[12,38]$. Therefore, there are presumably still sufficient levels of key compensatory miRNAs to regulate $\mathrm{Ca}^{2+}$ homeostasis in activated Dicer ${ }^{f / f f} \mathrm{CD}^{+} \mathrm{T}$ cells. 


\section{Cellular Physiology Cell Physiol Biochem 2016;39:1360-1368

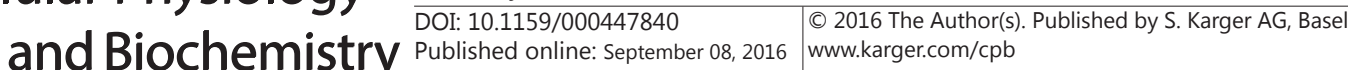 \\ Zhang et al.: Dicer Controls the Ca ${ }^{2+}$ Entry in T Cells}

Stimulation of T cells with anti-CD3 and anti-CD28 initiates a cascade of signalling events resulting in activation of various downstream pathways such as PI3K/mTOR, JAK/ Stat etc [39]. The influence of miRNAs on SOCE and thus activation of T lymphocytes may play a role in enhancing $\mathrm{T}$ lymphocyte activation and function. Limiting the extent and duration of TCR signalling ensures a tightly constrained response, protecting cells from harmful effects of chronic activation [28]. MiRNAs play an additional role in T cell activation through their regulation of mTOR, which is important for regulating the strength of TCR signalling leading to activation or anergy [40]. In contrast to Dicer ${ }^{f / f} \mathrm{CD}^{+} \mathrm{T}$ cells, Dicer ${ }^{\Delta / \Delta} \mathrm{CD} 4^{+} \mathrm{T}$ cells fail to adequately discriminate between activating and anergy-inducing stimuli as the TCR signal can elicit full activation with effective functions or state of anergy [40]. We speculate that $\mathrm{Ca}^{2+}$ signalling could also play a decisive role in this process because in the absence of miRNAs there was no significant increase in SOCE upon activation in between activated and unactivated $\mathrm{CD}^{+} \mathrm{T}$ cells from Dicer ${ }^{\Delta / \Delta}$ mice. Further studies are required to find out which key miRNAs are involved in $\mathrm{Ca}^{2+}$ homeostasis.

\section{Conclusion}

The present observations uncovered a novel role of miRNAs in the regulation of $\mathrm{Ca}^{2+}$ entry into $\mathrm{CD} 4^{+} \mathrm{T}$ cells. Further studies are required to define the specific miRNAs and target genes necessary for the regulation of $\mathrm{Ca}^{2+}$ entry into $\mathrm{T}$ cells. In any case, our results suggest that miRNAs are essential for the maintenance of $\mathrm{Ca}^{2+}$ homeostasis. Our study could have an important implication in infection, autoimmunity and cancer progression.

\section{Acknowledgements}

The authors gratefully acknowledge the meticulous preparation of the manuscript by Tanja Loch and Lejla Subasic and Elfried Farber for technical help. The authors are also thankful to Dr. Jakob Völkl for writing the permission for animal breeding. The Research is supported by DFG (F.L.) and Open Access Publishing Fund of Tuebingen University. MSS is supported by EMBO Long-term Fellowship (ATLF20-2013). Both SZ and YZ are supported by China Scholarship Commission.

\section{Disclosure Statement}

The authors of this manuscript state that they do not have any financial conflict of interests and nothing to disclose.

\section{References}

1 Alewine C, Kim BY, Hegde V, Welling PA: Lin-7 targets the Kir 2.3 channel on the basolateral membrane via a L27 domain interaction with CASK. Am J Physiol Cell Physiol 2007;293:C1733-1741.

2 Feske S, Skolnik EY, Prakriya M: Ion channels and transporters in lymphocyte function and immunity. Nat Rev Immunol 2012;12:532-547.

3 Fracchia KM, Pai CY, Walsh CM: Modulation of T Cell Metabolism and Function through Calcium Signaling. Front Immunol 2013;4:324.

4 Oh-Hora M, Komatsu N, Pishyareh M, Feske S, Hori S, Taniguchi M, Rao A, Takayanagi H: Agonist-selected $\mathrm{T}$ cell development requires strong $\mathrm{T}$ cell receptor signaling and store-operated calcium entry. Immunity 2013;38:881-895. 


\section{Cellular Physiology Cell Physiol Biochem 2016;39:1360-1368 \begin{tabular}{ll|l} 
and Biochemistry & Dublished online: September 08, 2016 & $\begin{array}{l}\text { (c) } 2016 \text { The Author(s). Published by S. Karger AG, Basel } \\
\text { www.karger.com/cpb }\end{array}$ \\
\hline
\end{tabular} \\ Zhang et al.: Dicer Controls the $\mathrm{Ca}^{2+}$ Entry in T Cells}

5 Oh-Hora M, Yamashita M, Hogan PG, Sharma S, Lamperti E, Chung W, Prakriya M, Feske S, Rao A: Dual functions for the endoplasmic reticulum calcium sensors STIM1 and STIM2 in T cell activation and tolerance. Nat Immunol 2008;9:432-443.

6 Shaw PJ, Feske S: Regulation of lymphocyte function by ORAI and STIM proteins in infection and autoimmunity. J Physiol 2012;590:4157-4167.

7 Waite JC, Vardhana S, Shaw PJ, Jang JE, McCarl CA, Cameron TO, Feske S, Dustin ML: Interference with $\mathrm{Ca}(2+)$ release activated $\mathrm{Ca}(2+)(\mathrm{CRAC})$ channel function delays T-cell arrest in vivo. Eur J Immunol 2013;43:3343-3354.

8 Feske S, Gwack Y, Prakriya M, Srikanth S, Puppel SH, Tanasa B, Hogan PG, Lewis RS, Daly M, Rao A: A mutation in Orai1 causes immune deficiency by abrogating CRAC channel function. Nature 2006;441:179185.

9 Ma J, McCarl CA, Khalil S, Luthy K, Feske S: T-cell-specific deletion of STIM1 and STIM2 protects mice from EAE by impairing the effector functions of Th1 and Th17 cells. Eur J Immunol 2010;40:3028-3042.

10 McCarl CA, Khalil S, Ma J, Oh-hora M, Yamashita M, Roether J, Kawasaki T, Jairaman A, Sasaki Y, Prakriya M, Feske S: Store-operated Ca2+ entry through ORAI1 is critical for T cell-mediated autoimmunity and allograft rejection. J Immunol 2010;185:5845-5858.

11 Bartel DP: MicroRNAs: target recognition and regulatory functions. Cell 2009;136:215-233.

12 Bronevetsky Y, Ansel KM: Regulation of miRNA biogenesis and turnover in the immune system. Immunol Rev 2013;253:304-316.

13 Carthew RW, Sontheimer EJ: Origins and Mechanisms of miRNAs and siRNAs. Cell 2009;136:642-655.

14 Filipowicz W, Bhattacharyya SN, Sonenberg N: Mechanisms of post-transcriptional regulation by microRNAs: are the answers in sight? Nat Rev Genet 2008;9:102-114.

15 Inui M, Martello G, Piccolo S: MicroRNA control of signal transduction. Nat Rev Mol Cell Biol 2010;11:252263.

16 Lindsay MA: microRNAs and the immune response. Trends Immunol 2008;29:343-351.

17 Liu J, Wu CP, Lu BF, Jiang JT: Mechanism of T cell regulation by microRNAs. Cancer Biol Med 2013;10:131137.

18 Lodish HF, Zhou B, Liu G, Chen CZ: Micromanagement of the immune system by microRNAs. Nat Rev Immunol 2008;8:120-130.

19 Lu LF, Liston A: MicroRNA in the immune system, microRNA as an immune system. Immunology 2009;127:291-298.

20 O'Connell RM, Rao DS, Chaudhuri AA, Baltimore D: Physiological and pathological roles for microRNAs in the immune system. Nat Rev Immunol 2010;10:111-122.

21 Agarwal V, Bell GW, Nam JW, Bartel DP: Predicting effective microRNA target sites in mammalian mRNAs. Elife 2015;4:doi: 10.7554/eLife.05005.

22 Rupp LJ, Brady BL, Carpenter AC, De Obaldia ME, Bhandoola A, Bosselut R, Muljo SA, Bassing CH: The microRNA biogenesis machinery modulates lineage commitment during alphabeta T cell development. J Immunol 2014;193:4032-4042.

23 Cobb BS, Hertweck A, Smith J, O'Connor E, Graf D, Cook T, Smale ST, Sakaguchi S, Livesey FJ, Fisher AG, Merkenschlager M: A role for Dicer in immune regulation. J Exp Med 2006;203:2519-2527.

24 Cobb BS, Nesterova TB, Thompson E, Hertweck A, O'Connor E, Godwin J, Wilson CB, Brockdorff N, Fisher AG, Smale ST, Merkenschlager M: T cell lineage choice and differentiation in the absence of the RNase III enzyme Dicer. J Exp Med 2005;201:1367-1373.

25 Chong MM, Rasmussen JP, Rudensky AY, Littman DR: The RNAseIII enzyme Drosha is critical in T cells for preventing lethal inflammatory disease. J Exp Med 2008;205:2005-2017.

26 Liston A, Lu LF, O'Carroll D, Tarakhovsky A, Rudensky AY: Dicer-dependent microRNA pathway safeguards regulatory T cell function. J Exp Med 2008;205:1993-2004.

27 Feske S, Prakriya M, Rao A, Lewis RS: A severe defect in CRAC Ca2+ channel activation and altered K+ channel gating in T cells from immunodeficient patients. J Exp Med 2005;202:651-662.

28 Bhavsar SK, Schmidt S, Bobbala D, Nurbaeva MK, Hosseinzadeh Z, Merches K, Fajol A, Wilmes J, Lang F: AMPKalpha1-sensitivity of Orai1 and $\mathrm{Ca}(2+)$ entry in T - lymphocytes. Cell Physiol Biochem 2013;32:687698.

29 Singh Y, Garden OA, Lang F, Cobb BS: MicroRNA-15b/16 Enhances the Induction of Regulatory T Cells by Regulating the Expression of Rictor and mTOR. J Immunol 2015;10.4049/jimmunol.1401875. 


\section{Cellular Physiology Cell Physiol Biochem 2016;39:1360-1368 \begin{tabular}{ll|l} 
DOI: 10.1159/000447840 & $\begin{array}{l}\text { O 2016 The Author(s). Published by S. Karger AG, Basel } \\
\text { www.karger.com/cpb }\end{array}$
\end{tabular} \\ Zhang et al.: Dicer Controls the $\mathrm{Ca}^{2+}$ Entry in T Cells}

30 Singh Y, Kaul V, Mehra A, Chatterjee S, Tousif S, Dwivedi VP, Suar M, Van Kaer L, Bishai WR, Das G: Mycobacterium tuberculosis controls microRNA-99b (miR-99b) expression in infected murine dendritic cells to modulate host immunity. J Biol Chem 2013;288:5056-5061.

31 Bissinger R, Modicano P, Alzoubi K, Honisch S, Faggio C, Abed M, Lang F: Effect of saponin on erythrocytes. Int J Hematol 2014;100:51-59.

32 Zhou X, Jeker LT, Fife BT, Zhu S, Anderson MS, McManus MT, Bluestone JA: Selective miRNA disruption in T reg cells leads to uncontrolled autoimmunity. J Exp Med 2008;205:1983-1991.

33 Oh-hora M, Rao A: Calcium signaling in lymphocytes. Curr Opin Immunol 2008;20:250-258.

34 Christo SN, Diener KR, Hayball JD: The functional contribution of calcium ion flux heterogeneity in T cells. Immunol Cell Biol 2015;93:694-704.

35 Greenberg ML, Yu Y, Leverrier S, Zhang SL, Parker I, Cahalan MD: Orai1 function is essential for T cell homing to lymph nodes. J Immunol 2013;190:3197-3206.

36 Kim KD, Srikanth S, Yee MK, Mock DC, Lawson GW, Gwack Y: ORAI1 deficiency impairs activated T cell death and enhances T cell survival. J Immunol 2011;187:3620-3630.

37 Christo SN, Diener KR, Nordon RE, Brown MP, Griesser HJ, Vasilev K, Christo FC, Hayball JD: Scrutinizing calcium flux oscillations in T lymphocytes to deduce the strength of stimulus. Sci Rep 2015;5:7760.

38 Bronevetsky Y, Villarino AV, Eisley CJ, Barbeau R, Barczak AJ, Heinz GA, Kremmer E, Heissmeyer V, McManus MT, Erle DJ, Rao A, Ansel KM: T cell activation induces proteasomal degradation of Argonaute and rapid remodeling of the microRNA repertoire. J Exp Med 2013;210:417-432.

39 Merkenschlager M, von Boehmer H: PI3 kinase signalling blocks Foxp3 expression by sequestering Foxo factors. J Exp Med 2010;207:1347-1350.

40 Marcais A, Blevins R, Graumann J, Feytout A, Dharmalingam G, Carroll T, Amado IF, Bruno L, Lee K, Walzer T, Mann M, Freitas AA, Boothby M, Fisher AG, Merkenschlager M: microRNA-mediated regulation of mTOR complex components facilitates discrimination between activation and anergy in CD4 T cells. J Exp Med 2014;211:2281-2295. 